\section{Index for 1995}

Page number references to Volume 18 are listed. Abbreviations: A, article; BR, book review; CR, conference report; $\mathrm{E}$, editorial; L, letter to the Editor; NR, news report.

Africa.

See High grade gneiss terrains (CR); Geological Society of Africa (NR); IGCP 348 (CR)

Alkaline-ultramafic igneous rocks. See Vasiliev, Y R and Zolotukhin, V V (A)

Asia.

See China; Tenth Himalaya-Karakoram-Tibet workshop (CR); Ren Jishun Jin Xiaochi (NR); IGCP Project 368 (CR); IGCP projects 306,321 and 359 (CR); Seismotectonics and geodynamics of the Himalaya (CR); Vasiliev, Y R and Zolotukhin, V V (A)

Baer, G and Heimann (eds.).

Physics and chemistry of dykes (BR by Tarney) 191

Bell D H (ed.) Landslides, Volume 3 (BR by Cruden) 135

Bolin Cong and Qincheng Wang. Ultra-high-pressure metamorphic rocks in China (A) 91

Bonham-Carter, G F. Geographic information systems for geoscientists (BR by Loudon) 132

Caribbean geology. 1995 conference (14th), Trinidad (CR) 120

Chen $\mathrm{Xu}$ and others.

Correlation of the Ordovician rocks of China. Correlation chart and explanatory notes, edited by Webby, B D (BR by Williams) 134

China.

See Bolin Cong and Qincheng Wang (A); Chen Xu and others (A); Daoxian and others (A); Deshing $\mathrm{Li}$ and others (A); Guangzhi Tu (A); Guowei Zhang and others (A); Hongzhen Wang and Xuanxue Mo (A); Jeffery, D (L);

Mengxiong Chen and Zuhuang Cai (A); Qihan Shen and Xianglin Qian (A); Qingxuan Chen and others (A); Ren Jishun Jin Xiaochi (NR); Rongfu Pei and Dawei Hong (A); Sicheng Wang and others (A); Sitian Li and others (A); Tungsheng Liu and others (A); Wenzhu Lin and others (A); Xuchang Xiao and Tingdong Li (A); Xun Zhu (A); Yipeng Wang Xingyuan Ma (A); Yuchan Chen and Weiping Tao (A); Zhiqin Xu (A); Zongu Zhang and Yun Chen (A); Zunyi Yang and others (A)

Coal in China.

See Sitian Li and others (A)

Cosmochemistry.

See Wenzhu Lin and others (A)

Cowie, JW.

See Schidlowski, M and others (eds.) (BR)

Crawford, Tony. See Smellie, J L (BR)

Crow, M J. See Kretz, R (BR)
Cruden, D M

See Bell, D H (BR)

Daoxian and others.

Karst in China (A) 62

Data systems.

See Ruus, L G M (A); Bonham-Carter, G $\mathrm{F}$ (BR)

Deshing $\mathrm{Li}$ and others

The geology and hydrocarbon potential of petroliferous basins in China (A) 21

Devonian Stratigraphy.

See Walliser, $\mathrm{O} \mathrm{H}$ and others $(\mathrm{A})$

Dykes.

1995 international dyke conference (3rd) Israel (CR) 168; see also Baer, $G$ and Heimann (eds.) (BR)

Earth science for schools-an initiative in Sri Lanka. (NR) 180

Education and training in earth science. See Earth science for schools- an initiative in Sri Lanka (NR); Rose, $\mathrm{S}$ van and Bonson, R (BR)

Engineering geology. See Qingxuan Chen and others (A)

Environmental geology.

See Mengxiong Chen and Zuhuang Cai (A); Qingxuan Chen and others (A).

Water vapour in the climate system (NR); Zen, E-an (L); Geological Indicators of rapid environmental change (NR)

EuroGeoSurveys. (NR) 127

Fortune Head plaque unveiled. (NR) 127

Fyfe, W S. Beijing 1996 (E) 2

Geoindicators. See Geological indicators of rapid environmental change (NR)

Geological Society of Africa. (NR) 180

Geological indicators of rapid environmental change. (NR) 183

Geology of the eastern Mediterranean region. 1995 international symposium (2nd), Israel (CR) 166

Geomagnetic catalogue. (NR) 183

Granite.

See Rongfu Pei and Dawei Hong (A); IGCP Project 315 (CR)

Gros Morne Declaration. See Zen, E-an (L)

GSA. 1996 Penrose Conference, Creteexhumation processes: normal faulting, ductile flow and erosion (NR) 179

GSSP for Permian-Triassic. See Zunyi Yang and others (A)

GSSP for Eifelian-Givetian. See Walliser, $\mathrm{OH}$ and others (A)

Guangzhi Tu

Some problems relating to superlarge ore deposits in China (A) 83

Guowei Zhang and others.

The Qinling orogen and intracontinental orogen mechanisms (A) 36

High-grade gneiss terrains. 1994 field training course, Swaziland (CR) 118

Himalaya. See Seismotectonics and geodynamics of the Himalaya (CR); Himalaya-Karakoram workshop, 1996 (NR); Sinha, A K (ed) (BR); Xuchang Xiao and Tingdong Li (A)

Himalaya-Karakoram workshop. 1995 meeting, Switzerland (CR); 1996 meeting (NR) 180

Hongzhen Wang and Xuanxue Mo.

An outline of the tectonic evolution of China (A) 6

Husseini, M I Al-

Selected Middle East papers from The Middle East geoscience conference, 1994, Bahrain (BR by Whittaker) 189

Hydrocarbons in China. See Deshing Li and others (A)

Hydrogeology in China.

See Mengxiong Chen and Zuhuang Cai (A)

IAGOD

See SGA (Society for Geology Applied to Mineral Deposits) (CR); IGCP Project $357(\mathrm{CR})$

IGBADAT

Igneous databse accessible on the Internet (NR) 129

IGCP.

New projects accepted and starting in 1995 (NR) 124; New projects accepted and starting in 1996 (NR) 185

IGCP project 306.

1995 joint international symposium on the geology of South-east Asia and adjacent areas, Viet Nam (CR) 172; New observations on the Red River Fault (CR) 177

IGCP Project 315.

1995 meeting Correlation of rapakivi granites (6th), Brazil (CR) 175

IGCP Project 321. 1995 joint international symposium on the geology of South-east Asia and adjacent areas, Viet Nam (CR) 172; New observations on the Red River Fault (CR) 177

IGCP project 345 . Meetings in $1996(\mathrm{NR}) 183$

IGCP 348

The Mozambique and related belts: 1995 field workshop in the Natal metamorphic province, South Africa (CR) 165

IGCP Project 359.

1995 joint international symposium on the geology of South-east Asia and adjacent areas, Viet Nam (CR) 172; New observations on the Red River Fault (CR) 177

IGCP Project 364. 1995 field meeting, Trinidad (CR) 120

IGCP Project 368.

1995 thematic meeting-India and Antarctica during the Precambrian; crustal processes in east Gondwana, India (CR) 170

IGCP Project 381.

South Atlantic Mesozoic correlations (NR) 125

Index for 1994 152

India.

See Seismotectonics and geodynamics of the Himalaya (CR); IGCP 368 (CR)

INQUA

(NR) 183; 1995 symposium on terrestrial carbon (CR) 169 
IUGS.

What is IUGS? 199; Financial statement for 1994 and budget for 1995 (NR) 128

Jeffery, $D$.

The China issue (L) 146

Jenkins, D G.

Chronostratigraphic nomenclature and geological time (L) 146

Kretz, R

Metamorphic crystallisation (BR by Crow) 130

Lambiase, J J (ed.).

Hydrocarbon habitat in rift basins (BR by Munn) 132

Landon, S M.

Interior rift basins (BR by Whittaker) 188

Lisle, R J and Leyshon P R.

Stereographic projection techniques in structural geology (BR by Treaguus) 190

Loess in China. See Zongu Zhang and Yun Chen (A)

Loudon, $\mathrm{T} V$. See Bonham-Carter, G F (BR)

Maimecha-Kotui alkaline-ultramafic province.

See Vasiliev, Y R and Zolotukhin, V V (A)

Mathers, S J and Notholt, A J G (eds.). Industrial minerals in developing countries (BR by Teoh) 134

Mediterranean.

See Geology of the eastern Mediterranean (CR); Husseini, M I Al- (BR)

Mengxiong Chen and Zuhuang Cai. Groundwater resources and hydro-environmental problems in China (A) 66

Metamorphism.

See Bolin Cong and Qincheng Wang (A); Kretz, R (BR)

Metcalfe, I.

See Smith A G and others (BR)

Mineral resources in China.

See Yuchan Chen and Weiping Tao (A); Sitian Li and others (A); Deshing Li and others (A); Rongfu Pei and Dawei Hong (A); Guangzhi Tu (A); Sicheng Wang and others $(\mathrm{A})$

Mineral deposits.

See SGA (Society for Geology Applied to Mineral Deposits) (CR); Mathers, S J and Notholt, A J G (BR)

Morocco.

See Walliser, $\mathrm{O} \mathrm{H}$ and others (A)

Munn, $S$.

See Lambiase, J J (BR)

Ordovician System.

1995 international symposium, Las Vegas, USA (CR) 121

Pacrim III.

1995 Pacific Rim Congress, New Zealand (CR)

Palaeoclimate.

See Tungsheng Liu and others (A); Daoxian and others (A); Zongu Zhang and Yun Chen (A); Daoxian and others (A); Petit-Maire, $\mathrm{N}$ and Gua Zhengtang (NR)

Penrose Conference. See GSA (NR)

Petit-Maire, $N$ and Gua Zhengtang. In-phase Holocene climate variations in the present-day desert areas of China and northern Africa (NR) 181
Qihan Shen and Xianglin Qian.

Assemblages, episodes and tectonic evolution in the Archaen of China (A) 44

Qinghai-Tibet Plateau.

See Xuchang Xiao and Tingdong Li (A)

Qingxuan Chen and others.

Assessment of regional crustal stability and its application to engineering geology in China (A) 69

Qinling orogen.

See Guowei Zhang and others (A)

Rapakivi granite. See IGCP Project 315 (CR)

Ren Jishun Jin Xiaochi. New observations on the Red River Fault (NR) 177

Revised geological calender. (NR) 184

Rongfu Pei and Dawei Hong. The granites of south China and their metallogeny (A) 77

Rose, $S$ van and Bonson, $R$. The Earth atlas (BR by Sherlock) 132

Russia.

See Vasiliev, Y R and Zolotukhin, V V (A)

Ruus, L G M

Data, information and global change: how long will your data last? (A) 116

Schidlowski, $M$ and others (eds.). Early organic evolution-implications for mineral and energy resources (BR by Cowie) 130

Seismotectonics and geodynamics of the Himalaya. 1995 meeting, India (CR) 174

SGA (Society for Geology Applied to Mineral Deposits).

1995 meeting, Mineral deposits: from origin to environmental impact (3rd), Czech Republic (CR) 173

Shear zones in China. See Zhiqin $\mathrm{Xu}(\mathrm{A})$

Sherlock, G.

See Rose, $S$ van and Bonson, R (BR)

Siberian Platform.

See Vasiliev, Y R and Zolotukhin, V V (A)

Sicheng Wang and others.

The quantitive prediction and evaluation of mineral resources (A) 87

Sinha, A K (ed).

Himalayan orogen and global tectonics (BR by Sorkhabi) 133

Sitian Li and others.

Coal resources and coal geology in China (A) 26

Smellie, J L.

Volcanism associated with extension at consuming plate margins (BR by Crawford) 187

Smith A G and others.

Atlas of Mesozoic and Cenozoic coastlines (BR by Metcalfe) 190

Sorkhabi, R B See Sinha A K (BR)

Sri Lanka.

See Earth science for schools- an initiative in Sri Lanka (NR)

Stratigraphic correlation. See IGCP projects 306,321 and 359 (CR); Ren Jishun Jin Xiaochi (CR); Jenkins, D G (L); Walliser $\mathrm{O} H$ and others (A); Chen Xu and others (BR); Zunyi Yang and others $(A)$
Structural geology.

See GSA (NR); Seismotectonics and geodynamics of the Himalaya (CR);

Sinha, A K (ed) (BR); Yipeng Wang

Xingyuan Ma (A); Xuchang Xiao and

Tingdong Li $(A)$; Qihan Shen and Xian-

glin Qian (A); Hongzhen Wang and

Xuanxue Mo (A); Zhiqin Xu (A);

Himalaya-Karakoram workshop, 1996

(NR); Lisle, R J and Leyshon P R (BR)

Swaziland.

See High-grade gneiss terrains (CR)

Tarney, John.

See Baer, G and Heimann (eds.) (BR)

Tectonic evolution of China.

See Hongzhen Wang and Xuanxue Mo

(A); Xuchang Xiao and Tingdong $\mathrm{Li}$

(A); Qihan Shen and Xianglin Qian (A); Yipeng Wang Xingyuan Ma (A)

Teoh Lay Hock.

See Mathers, S J and Notholt, A J G (BR)

Treagus, Jack.

See Lisle, R J and Leyshon P R (BR)

Trinidad and Tobago Geological Society 1995 conference ( $3 r d$ ), Trinidad (CR) 120)

Tungsheng Liu and others. Quaternary research in China and global change (A) 54

Vasiliev, Y R and Zolotukhin, V V.

The Maimecha-Kotui alkaline-ultramafic province of the northern Siberian platform. Russia (A) 155

Viet Nam.

See IGCP projects $306 ; 321:$ and 359 (CR); Ren Jishun Jin Xiaochi (CR)

Walliser, $\mathrm{O} \mathrm{H}$ and others.

Definition of the Eifelian-Givetian Stage boundary (A) 107

Walshaw, R D (E) 106; (E) 154

Water vapour in the climate system. (NR) 180

Wenzhu Lin and others. Cosmochemistry in China (A) 95

Whittaker, A

See Landon, S M (BR); Husseini, M I $\mathrm{Al}$ - (BR)

Williams, $\mathrm{H}$. See Chen Xu and others (BR)

Xuchang Xiao and Tingdong $\mathrm{Li}$. Tectonic evolution and uplift of the Qinghai-Tibet Plateau (A) 31

Xun Zhu.

Progress and achievements in geological work in China (A) 3

Yipeng Wang Xingyuan Ma.

Basic characteristics of active tectonics in China (A) 73

Yuchan Chen and Weiping Tao Metallic and nonmetallic minerals in China (A) 17

Zen, E-an.

The Gros Morne Declaration (L) 146

Zhiqin Xu.

Large shear zones in the main orogenic belts of China (A) 41

Zongu Zhang and Yun Chen. New developments in the study of loess in China (A) 58

Zunyi Yang and others.

The Permian-Triassic boundary: the global stratotype section and point (A) 49 